\title{
EXPLORING SHARIAH MEASURES FOR CURBING JUDICIAL CORRUPTION IN NORTHERN NIGERIA
}

\author{
Ibrahim Imam ${ }^{1}$
}

\begin{abstract}
Corruption is imbedded in every facet of the Nigeria polity. The judiciary is not exempted from this phenomenon. Corruption is so well established in the country that all efforts towards fighting corruption seem unworkable. The Nigerian government is constitutionally organized as three branches: the Legislature, Executive and the Judiciary, all under the doctrine of separation of powers. These three arms of government are expected to work under a symbiotic relationship in addressing corruption. However, the third body, which is saddled with the responsibility of interpreting the laws and determining dispute, is also affected by the menace of corruption. Thus, this study attempts to explore the Islamic perspectives on judicial corruption and its relevance to the Nigerian situation. We found that corruption within the judicial system undermined development and fighting against it under the conventional laws is unworkable. Thus, attempts should be made to employ Islamic principles to remedy this issue, especially when the Constitution recognizes Islamic Law as an applicable and alternative legal system in Nigeria.
\end{abstract}

Keywords: Shariah, corruption, judiciary, government, legal system

1 Senior Lecturer, Department of Public Law, Faculty of Law, University of Ilorin, Ilorin, Nigeria, omotosho20060@yahoo.com 


\section{INTRODUCTION}

A well-functioning, independent, and impartial justice system is crucial in order to address corruption effectively. However, the Nigerian judicial institution itself is corrupt despite its importance in tackling this issue. Consequently, corruption has eroded citizens' trust in the courts' impartiality, thereby harming all the core judicial constitutional functions, such as settlements in matters of dispute, maintenance of rule of law, enforcement, upholding the citizens' fundamental rights, and sanctioning compliance on the other branches when they act in contravention to the Nigerian Constitution.

However, the adverse effect of corruption on democratic governance has received little attention from Shariah scholars. It is against this background that this study explores the relevance of Islamic Law as panacea to judicial corruption in Nigeria. Accordingly, the phenomenon of corruption cannot be adequately understood - neither a preferred alternative be considered appropriate - without examining the theoretical understanding of the concept, identifying its causes, contemporary government efforts in fighting it, and reasons why these efforts have failed.

\section{THEORETICAL ISSUES}

\section{Concept/Meaning of Corruption}

The word 'corruption' is connected with acts such as bribery, extortion, buying influence, nepotism, favoritism, fraud, and embezzlement. ${ }^{2}$ The word comes from the Latin verb rumpere, or "to break". ${ }^{3}$ This phenomenon indicates decadence prevalent in the ethical, moral, social, or administrative code of conduct in society. ${ }^{4}$ In this respect, corruption can be thought of as the betrayal and abuse of trust for private benefit. However, scholars have described corruption from different perspectives. ${ }^{5}$ For instance, Annan posits that "corruption hurts the poor disproportionately by diverting funds intended for

2 S. 8-13 EFCC ACT (Nigeria) (2004).

3 Schleifer, A. \& Vishny, R., 'Corruption,' Quarterly Journal of Economics, 108/3 (1993): 599-617.

4 Stapenhurst, F. and Langseth, P., 'The Role of Public Administration in Fighting Corruption', International Journal of Public Sector Management, 10/5 (1997): 311-330.

5 Stapenhurst, F. and Langseth, P., 'The Role of Public Administration in Fighting Corruption.' 
development, undermining a government's ability to provide basic services, equal educational opportunity, accessible health care, feeding inequality and injustice and discouraging foreign investment and aid". ${ }^{6}$ To Osoba, "corruption can be defined as anti-social behaviour conferring improper benefits contrary to legal and moral norms, and which undermines the authorities' capacity to secure the welfare of all citizens."

In Black's Law the word 'corruption' indicates impunity or debasement, and when found in the criminal law, it means depravity or gross impropriety. It also means the act of doing something with an intent to give some advantages inconsistent with official duty and the rights of others; a fiduciary's or official's use of a station or office to procure some benefit either personally or for someone else, contrary to the rights of other. ${ }^{8}$ According to Nye, corruption is:

"A behaviour, which deviates from the normal duties of a public role because of private relationships (family, close private clique), pecuniary or status gain; or violates rules against the exercise of certain types of private relationship. This includes such behaviour as bribery (use of reward to pervert the judgment of a person in a position of trust); nepotism (bestowal of patronage by reason of astrictive relationship rather than merit); and misappropriation (illegal appropriation of public resources for private-regarding uses)." 9

In his own perspective, Ubeku, describes corruption thus as "transactions [which] usually include bribery fraud (such as inflation of contract sums by public officials), unauthorised variation of contracts, payment for jobs not executed, payment of ghost workers, overpayment of salaries and allowances to staff, diversion of government revenue by public officials, and deliberate irregularities in the management of accounting procedures." 10

6 Stapenhurst, F. and Langseth, P., 'The Role of Public Administration in Fighting Corruption.'

7 Osoba, S. 'Corruption in Nigeria: Historical Perspectives', Review of African Political Economy, 23/69 (1996): 371-386.

8 Bryan A. G., Black's Law Dictionary, $8^{\text {th }}$ ed. (USA: Thomson West, 2007), 371.

9 Nye, J. S., 'Corruption and Political Development: A Cost Benefit Analysis,' in American Political Science Journal, ed. Arnold J. H., 51/2 (1967): 566-67

10 Ubeku, A. K., 'The Social and Economic Foundations of Corruption and Other Economic Crimes in Nigeria', Perspectives on Corruption and Other Economic Crimes in Nigeria, ed. Ajibola Bala (Lagos: Federal Ministry of Justice, 1991), 41-43. 
Corruption is; "the perversion of the integrity or state of affairs through bribery, favour, or moral depravity"." Lodge observes that "political corruption is located within the institutions of government legislatures, courts, bureaucracies and statutory bodies such as parastatals, corporations or commissions. It is constituted by transactions or exchanges of public resources and benefits between actors, some or all of whom are officials or public representatives". ${ }^{12}$ Inferentially, from the above descriptions of corruption, there can be no clear distinction between initiator and receiver; in the sense that the initiator (giver of the bribe) who is usually seeking an underserved advantage from the receiver (receiver of bribe) is as well guilty of corruption. On this ground, if ethics are good, it means that corruption must be corrosive to the initiator, along with society as a whole. ${ }^{13}$

There is also a cultural dimension inferable from these descriptions to the extent that such actions like officials demanding bribes are considered corrupt in virtually all societies, whereas attitudes to gift-giving and cronyism vary from country to country. ${ }^{14}$ In another perspective, the definitions make clear that corruption takes place not only through public officials, but also by those in a position of trust in private enterprises or non-profit organizations. Indeed, most government corruption involves a private sector entity.

From the forgoing definitions it is understood that corruption involves an act by public officials that is detrimental to the welfare of the public through illegal accumulations of wealth for the sake of their private goals. In other words, it refers to the utilization of official privilege for private accumulation and behaviours that deviates from the formal rules of conduct governing the actions of someone in a position of public authority. Arguably, while corruption is tied particularly to acts of bribery, misappropriation, or embezzlement, it is a general term covering the misuse of authority as a result of the desire for personal gain.

Obviously, no definition of corruption is all encompassing thus it is worth noting that any attitude which falls short of the generally acceptable standard

11 Otite, O., Sociological Study of Corruption in Nigeria (Ibadan: Ibadan University Press, 1986), 76.

12 Lodge, R., 'Political Corruption in South Africa', Journal of African Affairs, 97 (1998): 66.

13 Zafar, I., \& Marvyn K. L., Governance and Corruption: Can Islamic Society and the West Learn from Each Other? the American Journal of Islamic Social Sciences, 19(12) (2013) 2

14 Zafar, I., \& Marvyn K. L., 'Governance and Corruption: Can Islamic Society and the West Learn from Each Other?' 2-3. 
of moral behavior, and is rationalized for private gain or reward against the interest of society, is corruption. It has been proposed that corruption in the most recent time - especially before the election of President Muhammadu Buhari in 2015 - has reached its apex and is notoriously rooted in Nigerian culture. ${ }^{15}$ Arguably, what used to be viewed as cases of abnormal attitude on the part of citizens and political office holders has now become an acceptable norm.

\section{Causes of Judicial Corruption in Nigeria}

The crime of judicial corruption manifests itself in different ways. It is a plain truth that the Nigerian judiciary has varying operational difficulties, ranging from serious ethical problems, an increasingly nepotistic mode of appointing judges - and elevation to the higher judicial benches - and cases of perversions of justice. Openly, eminent jurists and senior citizens are decrying the situation whereby corruption is eating deep into the heart of the judiciary. ${ }^{16}$ Among several other identified causes of judicial corruption are: inadequate remuneration for the judicial officials, poor terms and conditions of service, and greed. Scholars have also explored the nature of the discretionary power of the judiciary as a determinant of corruption by arguing that a wide discretionary power exercised by judges in civil and criminal matters creates more opportunities for corruption. It has also been identified that undue interference by political officials in judicial proceedings in an attempt to pervert the cause of justice constitutes another reason for corruption in the judiciary. ${ }^{17}$ In the same paradigm, judicial corruption continues to manifest itself from the entrenched culture of corruption in society as a whole. This confirms the widely held view that corruption is entrenched in every facet of the Nigerian polity. Additionally, it has been established that excessive workload due to insufficient personnel and inadequate and/or antiquated equipment contribute

15 The recent revelations on the misappropriation and embezzlement of 2 Billion Dollars meant for the purchase of arms to deal with Boko Haram speaks volumes on how government officials (former National Security Adviser to former President Jonathan, chairman of Daar Communication Raymond Dokpesi and Attahiru Bafarawa) are engrossed in corruption. THE NATION (NIGERIA), December 7, 2015, 1, 6 .

16 Ogunye, J., A New Nigerian Judiciary is Necessary, Sahara Reporters Commentary (2011), 14: 29.

17 Oyebode, A., 'The Judiciary, Corruption and Democratization,' Corruption and Democratisation in Nigeria, ed. Gboyega, A. (Ibadan: Ibadan University Press, 1996), 81-90. 
to corruption in the judiciary. ${ }^{18}$ So also is the issue of inaction or ineffective disciplinary action against identified corrupt judicial officers and undue protection of corrupt officers by their superiors. There is also the problem of an inadequate supervision of judicial officers and staff as well as a conflict of interest on the part of judicial officers. It is also evident that procedural rules and regulations which are conducive to corruption are in no small measure contributor to menace of corruption in Nigeria.

Without mystifying reality, factors garnered from existing literature establish the causes fuelling corruption in the judicial arm of the government in Nigeria. These factors have contributed in no small measure from preventing corruption to abate and undermine the judiciary's integrity as a fighter of corruption. ${ }^{19}$ The degree of judicial corruption is a function of multiple variables interacting with each other in almost every aspect of society.

\section{Government Efforts in Curbing Corruption}

Successive governments in response to the growing nature of corruption in Nigeria have strived to deal with the phenomenon through anti-graft legislation and institutions since independence in $1960 .{ }^{20}$ Strategies were introduced and anti-corruption legislations codified in relevant laws. For instance, there are anti-corruption sections contained in the Criminal Code (Chapter C38) and the Penal Code (Chapter P3) Ordinances. However, the first separate antigraft law that prescribes offences and penalties is the Miscellaneous Offences Decree of 1985. Notwithstanding the development in anti-corruption efforts, there has not been substantial change in legislation, but in most cases, the old laws are slightly modified and new agencies are empowered to handle it. The

18 Ribadu, N., 'Problems Associated with the Enforcement of Economic Crimes,' (Paper presented at the Nigeria Bar Association Conference Abuja, 2004).

19 See generally, Shah, A., 'Tailoring the Fight against Corruption to Country Circumstances,' Performance, Accountability and Combating Corruption, ed. Shah A. (Washington, D. C.: The World Bank Report, 2007); Rose-Ackerman, Susan, 'Trust, Honesty and Corruption: Reflections on the State Building Process,' European Journal of Sociology, 1/2 (2001): 38-41.

20 The institutional model started in 1977 by the Jaji declaration by president Olusegun Obasanjo; the Ethical Revolution of Shagari in 1981; War Against Indiscipline by Buhari in 1984; National Orientation Movement by Babangida in 1986; Mass Mobilization for Social Justice by Babangida in 1987; War Against Indiscipline and Corruption in 1996 by Abacha to the Independent Corrupt Practices (and Other Related Offences) Commission by Obasanjo in 2000 and the Economic and Financial Crime Commission 2002 by Obasanjo. 
following legislations are either wholly exclusive or partly directed towards anti-corruption in Nigeria: Miscellaneous Offences Act 1985; Failed Banks (Recovery of Debts and Financial Malpractices) Act of 1994 (amended in 1999); The National Drug Law Enforcement Agency Act (NDLEA) of 1988; Code of Conduct Bureau and Tribunal Act (CCBT) 2004 (Chap C15); Money Laundering Act of 1995 (amended in 2002 \& 2004); Foreign Exchange Act of 1995; Advance Fee Fraud (otherwise known as 419) and Related Offences Act of 1995; Independent and Corrupt Practices Commission Act (ICPC) 2000 (Chapter C31); and the Economic and Financial Crime Commission Act (EFCC) 2004 (Chapter E1). ${ }^{21}$

As evidenced from the summary of recent EFCC report, it was revealed that in 2014, 388 cases of corruption were prosecuted out of which 126 culprits were convicted, representing only $12.6 \%$. In 2013, 485 cases were filed out of which 117 officials indicted were convicted, representing only $12.65 \%$. While in 2012, 502 cases were instituted and 87 of the accused were convicted, representing only $30.95 \%$. Similarly, in 2011,417 corrupt cases were filed and 67 offenders were convicted, representing 46.83\%. And finally in 2010, 206 corrupt political officials were prosecuted representing $46.3 \%{ }^{22}$ It is also on record that between, 27 May 2015 to 25 May 2016 the EFCC has secured 114 convictions of corrupt individuals. This is evidence of the government's positive attempt at ant-corruption legislation in Nigeria. ${ }^{23}$

Empirical studies have equally established other examples of popular measures taken by the government in fighting corruption. These include dismissals of corrupt officials, confiscation of illicitly acquired assets, the establishment of commissions of inquiry, adoption of anti-corruption laws, and the creation of anti-corruption agencies. Additional efforts directed at fighting corruption include the setting up of ad hoc tribunals to try offenders. ${ }^{24}$

${ }^{21}$ The Acts are contained in the Laws of the Federal Republic of Nigeria (LFN), 2004.

22 Comparison of Conviction (2010-2014), 'EFCC Annual Report,' http://www. efccreport.org.ng, accessed on 18 May 2016.

23 The Nation, 27 May 2016, 1 \& 6.

24 Since President Muhammadu Buhari came into office in 2015, he's taken bold steps towards fighting corruption which has led to the recovery of N78.3 Billion Naira, \$185.5 Million Dollars, 3.5 Million Pound, and 11.2 Million Euros totaling N126.6 Billion Naira, looted by political office holders between 2009-2015. The funds were recovered between 29 May 2015 and 25 May 2016. See The Guardian 15 June 2016, 1 \& 6 
Notwithstanding the fact that studies have discussed the efforts of government in fighting corruption in various contexts, in most recent times it has failed to yield absolute positive results in eradicating or even reducing corrupt practices in Nigeria. Incidentally, studies have shown potential obstacles for successful anti-corruption enforcement. One such factor inhibiting the success in fighting corruption may be connected with an inefficient, formal, over-arching coordination and common strategic framework that enables anti-corruption agencies (EFCC, ICPC, CCB) to cooperate and work harmoniously together. ${ }^{25}$ Thus, the absence of this synergy among the agencies is affecting the fight against corruption, most especially in the realm of the institutional weaknesses of the ICPC, EFCC, and CCB. Such weaknesses include inadequate manpower, a lack of financial resources, and conflicts between agencies regarding powers to investigate and prosecute offenders. Other reasons for this failure have equally been attributed to a lack of strong political will on the part of the government to fight corruption, especially in light of some within the government who condone corruption, shield corrupt politicians from prosecution, or totally refuse to prosecute most of those indicted for corruption.

The contributions of stake holders in the justice sector cannot be overemphasized. Evidence has been adduced that some lawyers and judges are directly or indirectly contributing to the failure of the government's antigraft campaign, doing so by offering expert advice to indicted individuals, tactics of delaying litigation, and underhanded methods to frustrate the successful prosecution of their clients. ${ }^{26}$ There is also the problem of long and inconclusive prosecution of corruption cases in court, due partly to the judicial inability to effectively manage too many cases, and in particular, a lack of special courts to deal with corruption specifically. Other inhibiting factors are the attractiveness of corruption in society, poverty, unemployment, and the lack of political stability. ${ }^{27}$ There is also the act of legitimizing unpopular policies and the assumption that such efforts are more often than not driven by ulterior motives.

Existing empirical studies about people perceptions on government crusade against corruption indicate that majority of people $(54 \%)$ in the

25 Bello-Imam, I. B., The War Against Corruption in Nigeria: Problems and Prospects (Ibadan: Ibadan College Press \& Publishers, 2014), 52.

26 Lawyers, Judges and Others frustrating anti-graft war, The Nation (Nigeria) 17 June 2016, 8

27 Oko, O., 'Subverting the Scourge of Corruption in Nigeria: A Reform Prospectus,' Journal of International Law and Politics, 34 (2015): 401, 397-473. 
Global Corruption Barometer survey of 2014-15 considered their government to be ineffective and inefficient at fighting corruption. In Nigeria, the erosion of peoples' confidence in the government's ability to fight corruption grew astronomically between 2009 and 2015 during the regime of Former President Goodluck Ebele Jonathan. The available evidence indicates that about 68\% of people surveyed thought the government of the former president was ineffective or lacking in the fight against corruption. ${ }^{28}$

\section{The Basis for Shariah Option}

The paradigm for assessing and analyzing the Nigerian government's initiatives against corruption may be garnered from the various anti-graft legislations and commissions established by the National Assembly. However, the theoretical framework developed in this paper is founded on the exploration of Shariah principles as complimentary to the already excising laws fighting corruption in Nigeria. The theory is established on the proposition that: whereas the fight against corruption through anti-graft legislations and anti-corruption commissions have failed to deal with the phenomenon, an attempt is made on application of Islamic principles and values to complement the existing legislations in the fight against corrupt practices.

This paper's justification for the theory is based on the fact that Islamic law is one of the three constitutionally recognized legal systems applicable in Nigeria - including English Common Law and Customary Law. ${ }^{29}$ It is thus contended here that incorporating and employing Islamic principles does not mean possessing an absolute antidote to determine or deal with corruption, but that these measures can be used to set an agenda and compliment the campaign against corruption in Nigeria. Consequently, it is strongly assumed that with the application of Islamic principles, the desired objectives of establishing anti-graft laws and commissions can be achieved. ${ }^{30}$ Similarly, the rationale informing this approach is also premised on the importance Islam attaches to individual moral development, which must be reinforced by a powerful spiritual incentive system significant enough to strengthen, resolve

28 'Corruption and Poverty in Nigeria; Action Aid Nigeria,' available at www.action. org/nigeria, accessed on 6 June 2016.

29 The Nigeria Constitution recognizes tripod legal system, the English Common Law, Islamic Law and Customary Law.

30 See generally, Weimann, G., 'Judicial Practice in Islamic Criminal Law in Nigeria 2000 to 2004: A Tentative Overview,' Islamic Law \& Society Journal, 14/2 (2007): 240-286. 
and foster self-restraint against crime and criminality. ${ }^{31}$ In addition, the rules regulating Muslim judges' adjudicatory powers are more restrictive because the perception on judicial functions encompasses judges' moral and religious duties. It is thus argued that the country can employ Islamic principles to fight the menace of corruption.

While it is certain that dealing with the issues of corruption is a globally recognized goal, the vast majority of laws governing corrupt practices in society are man-made, created for specific purposes, and reflective of the overall interests and values of the people. ${ }^{32}$ In contrast, the laws regulating crime and corruption in Islam are divine, extensively elaborate in the Qur' $\bar{a} n$, a hadìth, and other secondary sources of the Shariah. ${ }^{33}$ That being the case, it is asserted that while society may enact, amend, or repeal its laws as it deems necessary, the same is not applicable to Islamic law. The clear implication of this is that while modern Western societies typically draw a line between things 'sacred' and 'secular', allowing the government to regulate public matters is not similar to the application of the Shariah. ${ }^{34}$ The broad body of Islamic Law draws no distinction between 'sacred' and 'secular'. ${ }^{35}$ In addition to setting forth God's

31 See generally Imber, C., The Islamic Legal Principle (Stanford: Stanford University Press, 1994), 22.

32 For instance, apart from the provisions of Criminal Code and Penal Code dealing with issues of corruption, the Nigerian National Assembly has enacted several legislations to deal with these issues, among which are: Corrupt Practices and Money Laundering (Prohibition) Act, No.7, of 2003, Cap. M18, LFRN, 2004, Independent Corrupt Practices and other Related Offences Commission (ICPC) Act No.6 of 2002 Cap. C31 LFRN., 2004. Economic and Financial Crime Commission, Act, No.1, of 2004, Cap. E1, LFRN, 2004, Advance Fee Fraud and Other Related Offences Act, No.62 of 2007, Cap. A6, LFRN 2004 etc. Those enacted before then include; Recovery of Public Property (Special Military Tribunal Act Cap. 389), Laws of the Federation of Nigeria 1990, Corrupt Practices Investigation Bureau, proposed by the Muritala Mohammed administration in 1975, and the Code of Conduct Bureau Act, (No. 61 of 1989, Cap. C15 LFRN, 2004) established in 1979 by the Second Republic Constitution and retained in the 1999 Constitution, Recovery of Public Property Act No.3 of 1984, Cap. R4, LFRN, 2004 and Failed Bank (recovery of Debts) and Financial Malpractice in Bank Act, No.18 of 1994, Cap. F2, LFRN, 2004. Despite the successes achieved by these measures, the situation remains unacceptable as corruption continues to permeate and pervade every facet of national life in Nigeria.

33 See generally Imber, C., The Islamic Legal Principle, 22.

34 Weiss, B. G., The Spirit of Islamic Law (Athens: University of Georgia Press, 1998), 64.

35 Kamal Mohammed Hashim, Principles of Islamic Jurisprudence (London: Cambridge Islamic Text Society, 1991), 168-188. 
laws for prayer, fasting, and professing the faith, the Shariah also deals with politics, economics, banking, trade, family, evidence and procedure, sexuality, dress, hygiene, diet, and criminals. ${ }^{36}$

The paper argues that judicial integrity, whether from Islamic principles or the Nigeria common law perspectives, is a derivative of the level of judicial accountability, which can only be fostered in the absence of corruption and where there is a fair and effective disciplinary process against corrupt judges. ${ }^{37}$ While it is important that judges perform their duties on the basis of facts and in accordance with the rule of law, this research contends that improper influences or corrupt practices must be avoided to sustain the public perception of a judiciary which is impartial and independent in its constitutional role as mediator.

\section{CORRUPTION IN NIGERIA}

Thereverberating effects of the failure ofleadership, corruption, mismanagement of public funds, and bad governance are being felt across all sectors and segments of the Nigerian polity. The effects are manifestly felt in the realm of unemployment, insecurity, crude oil thefts, dearth of infrastructures, problems in education, health services, transportation, accommodation, communication, affordable medicare, etc. ${ }^{38}$ Nigeria has remained lagging behind in social, political and economic developments, not to mention achieving fair and equitable justice from courts of law. ${ }^{39}$ Nigeria's social politico-economic history reveals that many of its leaders over the years have been using 'judicial manipulation' to shield themselves from prosecution against allegations of corruption. This explains the triumph of the leaders' ambitions for power over

$36 \quad$ Imber, C., The Islamic Legal Principle, 56.

37 See the UN Basic Principles on the Independence of the Judiciary, 7th UN Congress on the Prevention of Crime and the Treatment of Offenders, Milan, Italy, August 26-29, 1985 and 40/146 of December 13, 1985; UN GAOR, 40 ${ }^{\text {th }}$ Session, Supp. No. 53, UN Doc. a/40/53 (1985); The Bangalore Principles of Judicial Conduct, Adopted by the Judicial Group on Strengthening Judicial Integrity, as revised at the Roundtable Meeting of Chief Justices held at the Peace Palace, the Hague, the Netherlands, 25-26 November 2002.

38 Szeftel, M., 'Misunderstanding African Politics: Corruption and the Governance Agenda', Review of African Political Economy, 76 (1998): 219-240.

39 See generally; Pogoson, A. I., 'Globalization and Anti-Corruption Reform in Nigeria: 2003-2007,' in Anti-Corruption Reform in Nigeria Since 1999: Issues, Challenges and the Way Forward, vol. 3, ed. Ekweremadu, D. U. and Okafor E. E. (Ibadan: IFRA Special Research Issue, 2009), 123. 
the citizens' rights. ${ }^{40}$ The official figures recently placed in the public domain by the Nigerian Bureau of Statistics (NBS) capture and underscore the paradox of the Nigerian situation. ${ }^{41}$ The figures showed a copious inflow of proceeds from oil and a very sharp contrast between available resources and the living conditions of the populace. ${ }^{42}$ The Bureau's report has drawn public attention to the oft-repeated problem of mismanagement and failure of leadership. ${ }^{43}$

The judicial institution of government have over the years been drawn into the arena of corruption and appear to be deeply engrossed in excessive acts of impropriety, mismanagement of judicial power, and perversions of justice. In addition, Nigerian political leaders continue to employ all available means to attain power at all costs including the blatant rigging of elections, mismanagement of public funds, manipulation of census figures, violence, thuggery, arson, vandalism, religious strife, natonalism, tribalism, ethnic sentiments, and acts of brigandage. ${ }^{44}$

Nevertheless, the forms of corrupt activities prevalent in Nigeria can be summed up to include political corruption, bureaucratic corruption, electoral corruption, embezzlement and bribery. ${ }^{45}$ Political corruption, which takes place at the highest levels of authority, is a 'corruption of greed', affecting the manner in which judicial decisions are made. Bureaucratic corruption, which occurs in the public administration or the implementation end of politics, is the

40 Tignor, R., 'Political Corruption in Nigeria before Independence', Journal of Modern African Studies, 12/10 (1993): 175- 202.

41 There are several high profile cases of corruption in Nigeria that remain unresolved. Ayodele Fayose, the newly elected governor of Ekiti State in 2015, was once indicted for corruptly diverting a sum of N1.2 Billion when he was former governor of the state between 2003 and 2006. Joshua Dariye, former governor of Plateau State. was alleged to have diverted a sum of N300 Million in 2008. Saminu Tunki, a former governor of Jigawa State, diverted N36 Billion in 2007, etc. The Nation News Paper, (Nigeria) September 25, 2015, 2-3

42 For instance, on September 27, 2013, former CBN governor Sanusi Lamido Sanusi wrote the Former President Goodluck Jonathan that NNPC refused to repatriated to the Federation Account - in line with the constitutional requirement in section 162 (10) - an amount in excess of \$20 billion the value of oil lifted between January 2012 and July 2013. See Premium Times, (London) 26 September 2015

43 The Tribune (Nigeria), 4 April 2003, 17

44 Ugochukwu, B., Democracy by Court Order: An Analytical Evaluation of the 2007 Election Petition Tribunals in Nigeria (Lagos: Legal Defence Centre, 2009), 18-24.

45 Ribadu, N., 'Corruption: The Trouble with Nigeria', (A paper Presented at the 3rd Annual National Trust Dialogue, 2006), 19. 
'low level' corruption. ${ }^{46}$ This is the type of corruption the citizens encounter daily in places like hospitals, schools, local licensing offices, encounters with the police, taxing offices, etc. It is petty corruption of need that occurs when one obtains a bribe from a litigant and the public sector. ${ }^{47} \mathrm{~A}$ judiciary which is engrained with injustice and devoid of equality and fairness is inherently contributing to the instability in society.

\section{JUDICIAL CORRUPTION}

The role of the judiciary in any democratic governance is not only to be critical, but underscores the centrality of law in a polity. ${ }^{48}$ These roles extend to sustaining economic growth and development, protection fundamental rights of citizens, and sustaining human development which can only be effective in an environment where the judiciary is independent of any form of interference. ${ }^{49}$ Yet, manifestations of corruption seem to be at their worst in developing countries and countries in transition. It is now an undisputable fact that corruption is one of the main obstacles to the attainment of justice, peace, stability, sustainable development, democracy, and human rights around the globe.

International and regional human rights instruments recognise the fundamental right of everyone to due process of law, including rights to a fair and public hearing by a competent, independent, and impartial tribunal established by the law. ${ }^{50}$ The importance of these rights is underscored by the fact that the implementation of all other rights depends upon the proper and fair administration of justice. An essential element of the right to a fair trial is an independent and impartial tribunal. Another inherent element of a fair trial is the procedural equality of parties.

$\overline{46}$ See generally, Gloppen, S., Gargarella, R., and Skaar, E., eds., Democratization and the Judiciary: The Accountability Function of Courts in New Democracies (London: Frank Cass; 2004), 12.

47 Tignor, R., 'Political Corruption in Nigeria before Independence,' 175- 202.

48 Oyebode, A., 'The Judiciary, Corruption and Democratization,' Corruption and Democratisation in Nigeria, 81-90.

49 Buscaglia, E., Judicial Corruption in Developing Countries: Its Causes and Economic Consequences (Palo Alto, Stanford, CA: Hoover Institution Press, Passim 1999), 14.

50 Mauro, P., 'Corruption and Growth,' Quarterly Journal of Economics (1995): 681712 . 
In spite of the increasing rate of corruption in the other arms of the Nigerian government, corruption in the judiciary though been holistically confronted, still continue to manifest and not effectively managed. The National Judicial Council (NJC) has been working assiduously and sincerely in dealing with corruption among its members (the Bar and the Bench). The evidence of this fact is shown from disciplinary action meted out by the NJC against some judges found unworthy of remaining in their positions. For instance, very recently, Justice Muhammed Lambo Akanbi of the Federal High Court Port Harcourt was removed from his position by way of compulsory retirement due to his misconduct; ${ }^{51}$ Justice Egbo-Egbo was dismissed from the bench for giving a very controversial judgment in a case involving some parties in Anambra State; ${ }^{52}$ Justice Stanley Nnaji was found culpable of abuse of power, especially delivering controversial judgments in an electoral dispute; ${ }^{.3}$ members of the Akwa Ibom Election Tribunal were indicted for accepting bribe and dismissed by the NJC; and former Chief Judge of the Federal Capital Territory, alleged to have taken exhibit money from his court when he was serving in Sokoto prior to his resumption at the Federal Capital Territory, was equally dismissed by the NJC. ${ }^{54}$

Also, four judges, namely M. M. Adamu, T. Ahuta, James Isede, and A. M. Elelegwu of the Akwa Ibom State governorship, were dismissed from their posts on allegations of bribery in 2004. ${ }^{55}$ Similarly in 2005, justices Okwuchukwu Opene and David Adeniji, both of the Nigerian Court of Appeal, were removed from their posts for well-proven acts of corruptionin 2005, arising from their handling of the appeal in a senatorial contest in Anambra state. ${ }^{56}$ In fact, their judgment ended in a bizarre drama when members of the audience, in an expression of anger when the judgment was being read, forced the judges to flee in different directions. A committee set up under the auspices of the NJC and chaired by a retired judge of the Court of Appeal established that Opene took 15 million naira (US\$100,000) in bribes while Adeniji accepted 12 million naira (US\$80,000). The third judge, Kumai Bayang Akaahs, was said to have rejected the amount which was offered him and instead delivered a dissenting judgment. ${ }^{57}$

\footnotetext{
51 The Nation (Nigeria) 18 December 2015, 1

52 News Watch (Nigeria) 9 February 2004, 1-2

53 This Day, (Nigeria), 23 March 2004, 1 \& 55

54 Justice Observatory Journal, 2/1 (July 2004): 4-6; 57-63; and the Justice Observatory Journal, 5/1 (May 2007): 4.

55 The Nation (Nigeria), 16 March 2004.

56 This Day (Nigeria), 16 March 2005.

57 See generally Ibrahim Imam et al., 'Corruption in Nigeria: A Call for an Aggressive Legal Solution,' UNIZIK JIL (2010): 134-145.
} 
The most recent findings on the statistic of corruption in judiciary reveal that $82 \%$ of corrupt practices are perpetrated at the lower level Magistrate Courts, High Courts, and Federal High Court, while 12\% of such offences are committed in the Court of Appeal and $2 \%$ within the Supreme Court. ${ }^{58}$ Instructively, on the part of judiciary, with exception of the case of Federal Republic of Nigeria vs. Justice Garba Abdullahi, ${ }^{59}$ most allegations of corruption against judicial officials are usually dealt with by the NJC Disciplinary Committee.

\section{ISLAMIC PERSPECTIVE ON CORRUPTION}

It is instructive to explain from outset that the need to explore the Shariah perspectives on issues of corruption is premised on two reasons. First the Nigerian Constitution recognizes Shariah as an applicable legal system regulating the personal affairs of the Muslims. ${ }^{60}$ Second, the pervasive nature of corrupt practices in every segment of the country and the failure of government attempts through legislation and absence of political will to address the menace significantly creates the need to consider the Shariah as alternative mechanism to fighting corruption in Nigeria. However, the Shariah has a limited influence on the Nigerian legal system, notwithstanding the fact that the country operates on three branches of government. More so, Shariah as an encompassing legal system is only applicable in 12 Northern states of Nigeria and limited to Islamic personal matters only. ${ }^{61}$

Incidentally, for many people, religion is an important influence that shapes moral conduct, societal values, and concepts of social justice and have fact been the overriding consideration of Islamic faith. ${ }^{62}$ Therefore, Muslims do not, in good faith, compartmentalize their behaviour into religious and secular dimensions only, because their actions are considered bound by Islamic law which embodies an encompasses a set of duties, including etiquettes in all facets of life - public and private. ${ }^{63}$ Considering Muslims attachment to

58 'Corruption and Poverty in Nigeria; Action Aid Nigeria,' available at www.action. org/nigeria, accessed on 6 June 2016. See also Federal Republic of Nigeria, Report of Political Bureau, Abuja 2015.

59 Charge No KN/ANTI?ICPC/05 (Unreported).

60 See Section 277 of Nigerian Constitution 1999.

61 See Nigerian Constitution 19999 (as amended) sections 260 and 275, the Court has jurisdiction on Muslims personal law such as Waqf, Gift, Inheritance (succession) Custody of children, family disputes that marriage and divorce, etc.

62 Zubaida, S., Law and Power in the Islamic World (London: I.B. Tauris, 2003), 76.

63 See generally, Joseph Schacht, An Introduction to Islamic Law (London: Oxford Clarendon Press, 1973), 72. 
Islamic principle as all encompassing, what then is the Islamic perception on corruption?

The conception of corruption like any other aspects of Muslim life can be traced to the primary sources of Islamic law; that is the Qur'an (the revealed word of God) and the Sunnah (the practices and approvals of Prophet Muhammad (PBUH) and his Companions based on thousands of statements about what was said or done, found in the literature of the ahadith).$^{64}$ Therefore, under Islamic law, corruption refers to a broad spectrum of human behavioral digressions which are not compatible to Islamic principles and threaten the social, economic, and ecological balance of society and individuals. ${ }^{65}$ This may be exemplified in the following Qur'anic verses:

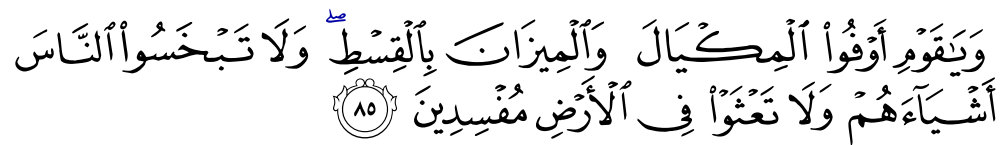

"Oh my people! Give full measure and full weight in justice, and wrong not people in respect of their goods. And do not do evil in the earth causing corruption."

(Surah al-Hūd, 11: 85)

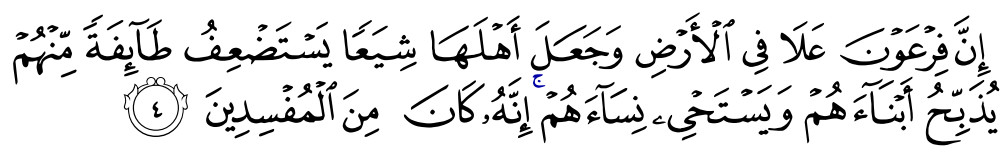

"Firaun exalted himself in the earth and made his people castes. A tribe among them he oppressed, killing their sons and spearing their women. He was of those work corruption."

(Surah al-Qașaș, 28: 4)

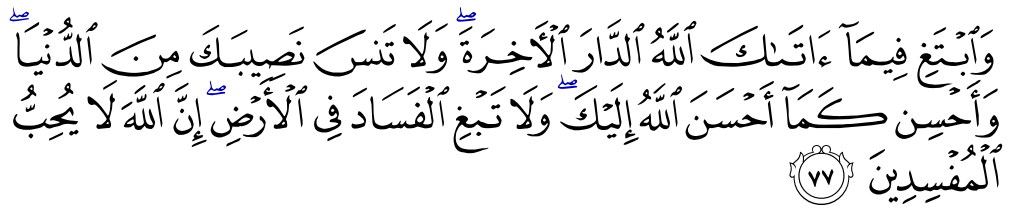

"But seek the abode of the hereafter in that which Allah has given you and neglect not your portion of the world, and be kind even as

64 Khadduri, M., The Islamic Conception of Justice (Baltimore: Johns Hopkins University Press, 1984), 135-141.

65 Zafar Iqbal \& Mervyn K. L., 'Governance and Corruption: Can Islamic Societies and the West Learn from Each Other?', American Journal of Islamic Social Sciences, 19 (2002): 12-13. 
Allah has been kind to you and seek not corruption in the earth, Allah loves not corrupters."

(Surah al-Qașaṣ, 28: 77)

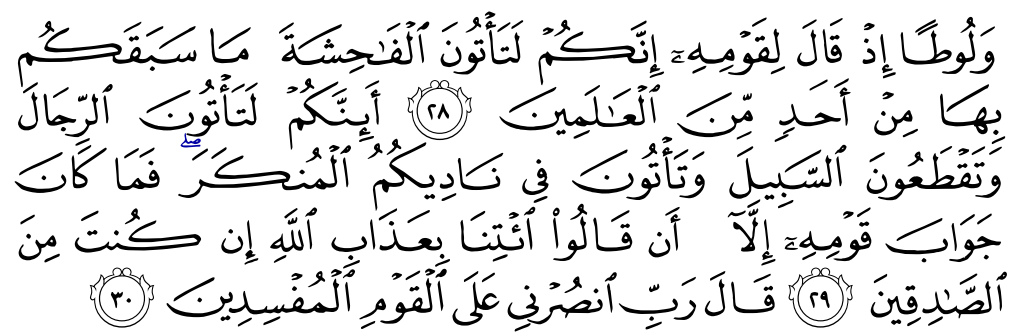

"As for that abode of the hereafter we assign it to those who seek not oppression in the earth, nor yet corruption. The sequel is for word off (evil). And lot! (Remember) when he said to his people you commit lewdness such has no creation deed before you. For do you not come into males, do you not the road (travelers), and do you not commit abomination in your meetings? But the answer of his people was only that they said bring Allah doom upon us if you are truth/teller! He said my Lord! Give me victory over people who work corruption."

(Surah al-'Ankabūt, 29: 28-30)

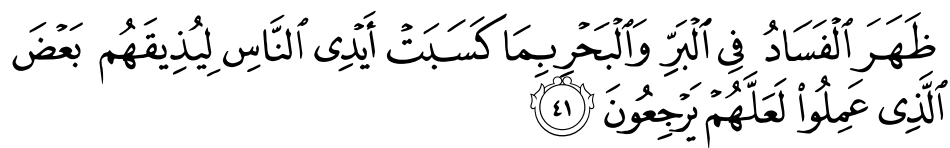

"Corruption appears on the land and seas because of (the evil) which men hands have done, that he may make the taste a part of that which they have done in order that they may return."

(Surah al-Rūm, 30: 41)

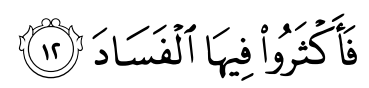

"And increased therein the corruption"

(Surah al-Fajr, 89: 12)

From the above Qur'anic verses, corrupt acts are explained in terms of being unjust with reference to their detrimental impacts on organizations and/ or people in accord to the universally accepted standards of moral behaviours. The negativity of such actions is that corruption distorts the harmonious 
relationships among diverse groups of people (religions, ethnicities, socieeconomic statuses, etc.). Understanding corruption from the Islamic law perspective demonstrates that the term corruption extends to the abuse of public office for private gain or mismanagement of public funds. The significance of which is explained in Qur' $\bar{a} n$ thus:

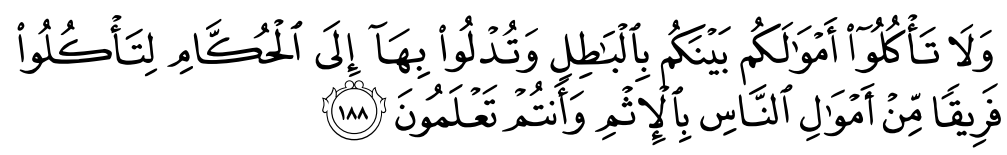

"And eat not your property among yourself in vanity, nor seek by it the hearing of the judges that you may knowingly devour a portion of the property of others wrongfully..."

(Surah al-Baqarah, 2: 188)

Islam prohibits political leaders, rulers, judges, decision-makers, and common or poor citizens from engaging or facilitating the unjustified appropriation of property or procuring a favourable ruling in exchange for bribery. ${ }^{66}$ This is explained in Qur' $\bar{a} n$ :

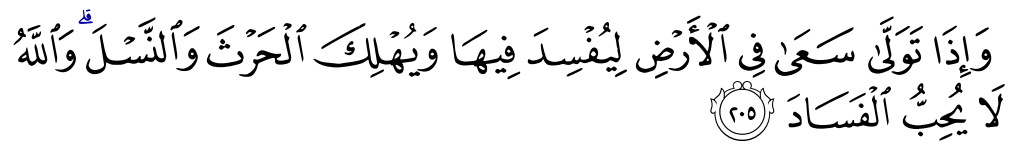

"... and when he goes away, he strives throughout the land to cause corruption therein and destroy crops and animals. And Allah does not like corruption..."

(Surah al-Baqarah, 2: 205)

Islam takes issues of corruption seriously because of its negatives effects on society and therefore admonishes the wealthy society to seek their wealth lawfully and not engage in actions that spread corruption (fasad) ${ }^{67}$ In Islam, the exemplary life of the Prophet Muhammad (PBUH) is significant. Thus, when discussing corruption, the prophetic Sunnah becomes important to provide illustrations of what is considered appropriate or inappropriate behaviour. There are ahâdith that describe or condemned corruption through a general sanction that censures the givers and the receivers of bribes or engages in acts of corruption. For example: "It was narrated by 'Abd Allāh Ibn Amr Ibn al-As

\footnotetext{
66 See generally, Bassiouni M., and Gamal B., 'The Shariah: Sources: Interpretation and Rule-Making', UCLA Journal, 1 (2002): 135, 150.

67 Surah al-Qașaṣ, 28: 77.
} 
that the Apostle of Allah (PBUH) cursed the one who offers bribe as well as one who accepts a bribe", ${ }^{68}$

The menace of corruption is addressed in the Shariah through reproaching abuse of trust placed in officials by the state such as accepting gifts, outright theft of public funds, and undermining rules in exchange for bribes on recommendation or due to family/tribal considerations. In summary, judicial officers are prohibited from making recommendations in exchange for gifts as such behavior falls under rashwa. ${ }^{69}$ The Prophet's (PBUH) way of fighting and preventing corruption was to warn against the appointment of people who sought a authority because such are positions of trust that must be given only to those possessing merit. In this respect, the Prophet (PBUH) was reported to have said:

$$
\text { عليه فئها مانة، وإنها يوم القيامة خذى الامن خذها بحقها وادى الذى }
$$

"Authority is a trust, and on the Day of Judgment it is a cause of humiliation and repentance except for one who fulfill its obligations and (properly) discharges the duties attendant thereon..." 70

The Shariah considers corruption a serious crime and simultaneously religious and criminal offences because of the serious harm it can bring to society, particularly when viewed from the perspective of those saddled with judicial responsibility. Therefore, they are punished, as the Qur'ān states:

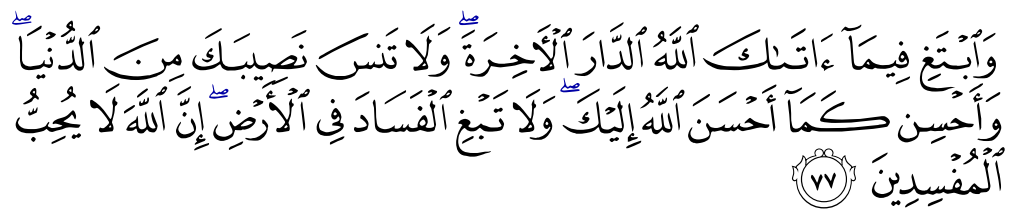

"But seek, with the wealth which Allah has bestowed on thee, the home of the Hereafter, nor forget thy portion in this world: but do thou good, as Allah has been good to thee, and seek not occasions for mischief in the land: for Allah loves not those who do mischief."

(Surah al-Qașaș, 28: 77)

68 Abū Dāwūd, Sunnan Abū Dāwūd, Book 24, Hadīth no. 3573 (Riyadh, Saudi Arabia: Darussalam Publishers and Distributors, 2008), 164-165.

69 Rosen, L., 'The Anthropology of Justice: Law as Culture in Islamic Society,' (1989): 224.

70 Abū Dāwūd, Sunnan Abū Dāwūd, Book 24, Hadìth no. 3573 (Riyadh, Saudi Arabia: Darussalam Publishers and Distributors, 2008), 164-165. 
Although judicial corruption is not considered in all its forms a moral offence, notwithstanding it encompasses all offences for which the Shariah does not prescribe a specific penalty. ${ }^{71}$ Judicial corruption is considered a crime in Islamic law because of the vital role judges play in the achievement of justice within the application of fairness between individuals. ${ }^{72}$ As such, the judiciary represents one of the most fundamental positions in the Islamic state. ${ }^{73}$ Muslim scholars include within the category of "judges and state governors" prosecutors, decision makers, rulers, and other public officials. The form of corruption of a judicial officer thus consists of either paying bribes to hold a judicial position or to facilitate an illegal ruling or judgment. ${ }^{74}$

In view of the above, Muslim scholars agree upon the prohibition of obtaining a judicial position in exchange for bribes as it represents "eating up" property for vanity, lack of integrity, dishonesty, and abuse of confidence and trust. This prevailing opinion can be inferred from the following hadith reported by 'Abd al-Rahman Ibn Samura, who said that:

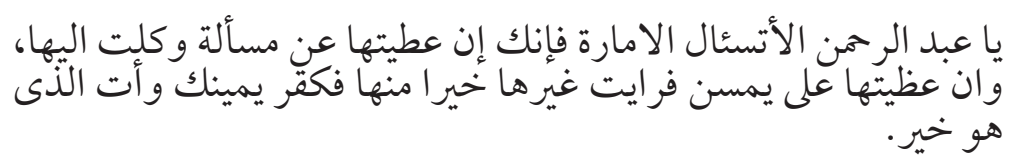

"The Messenger of Allah (PBUH) said to me: 'Abd al-Rahmān, do not ask for a position of authority, for if you are granted this position as a result of your asking for it, you will be left alone without God's help to discharge the responsibilities attendant thereon, and if you are granted it without making any request for it, God will help you in the discharge of your duties." 75

Similar evidence is the tradition narrated by 'Abd Allāh Ibn 'Amr Ibn alwhere he said that:

71 Sahịh Muslim, Knowledge, vol. 1, Book 2,0 Hadīth no. 4491, translated in University of California, Center for Muslim-Jewish Engagement, available at, http://cmje.org/, accessed on 20 September 2015.

72 Joseph Schacht, An Introduction to Islamic Law, 68.

73 Yusuf Abdullah al-Qardawi, The Lawful and the Prohibited in Islam (Shams Pirzada Trans., 1996), 108-110,

74 Hussein M., 'Bribery in Islamic Jurisprudence: A Comparative Analysis between Islamic Law and Positive Law,' Journal of Islamic Jurisprudence, 22 (1984).

75 Bukharī, Șah̄ịh al-Bukharī, Book of Knowledge, Book 20, Hadīth no. 4487, translated in University of California, Centre for Muslim-Jewish Engagement, available at hhttp://emje.org/ accessed on 20 September 2015. 


$$
\text { لعن رسول اله صلى الله عليه وسلم الراسي والمرتشي }
$$

"The Apostle of Allah (PBUH) cursed the one who offers bribe as well as the one who accepts a bribe." 76

Accordingly, judges in Islamic laws are duty bound to decide on the basis of evidence or beyond iota of doubt in criminal cases and the onus of honesty on the litigants.

Against this background, corruption in the form of bribery or influencing judges is linked to a lack of righteousness or the ideal of being God-fearing. ${ }^{77}$ Instructively, under Islamic law judicial rulings should at all times represent a balanced and divinely ordained way of life, firmly bound together in a common framework of maintaining fear of Almighty Allah SWT. Anything short of this amounts to corruption from an Islamic point of view. Ibn Kathir refers to accounts in al-Bukhari and Muslim in which Umm Salamah quotes the Prophet $(\mathrm{PBUH})$ as saying:

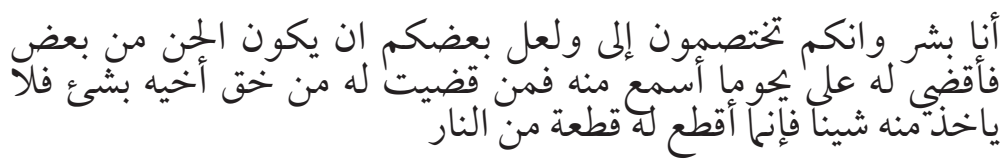

"I am only human. When you come to me for judgment, some of you may have a clearer piece of evidence, and I might be inclined to rule in their favor. If I give someone anything which is not rightly his, it would be as if I have given him a brand of fire; it is up to him to take it or leave it..." 78

Islam is all encompassing and takes care of all facets of human life. This makes Islamic law a well-integrated system which cannot be fragmented or disconnected. Judicial corruption is therefore a gross transgression and a most vile offense against Allah $^{79}$ as described in the Qur'ān:

76 Abū Dāwūd, Sunnan Abū Dāwūd, Knowledge, vol. 1, Book 24, Hadīth no. 3573, Translated in University California Center for Muslim-Jewish Engagement, available at http://cmje.org/ accessed 20 September 2015 see also Qur'ān 2 verse 188 supra.

77 Engy A., 'To Judge or not to Judge: A Comparative Analysis of Islamic Jurisprudential Approaches to Female Judges in the Muslim World (Indonesia, Egypt and Iran),' Fordham International Law Journal, 37 (2014): 309-372.

78 Bukharī, Sahīh al-Bukharī, Book 18, Hadīth no. 4247 (Riyadh, Saudi Arabia: Darussalam Publishers and Distributors, 2008),

79 Mohamed, A. A., 'Corruption and Bribery in Islam,' Annual Survey of International and Comparative Law, XVIII, ICL (2012): 171-242. 


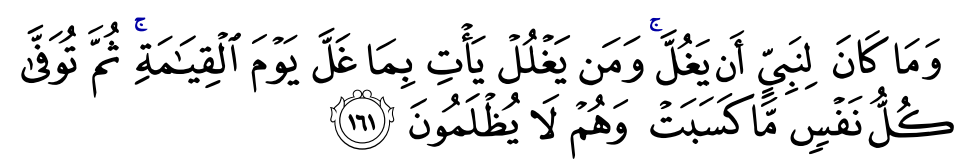

"It does not behoove a Prophet to act dishonestly, for he who acts dishonestly shall be faced with his dishonesty on the Day of Resurrection. Everyone will then be paid in full what he has earned and none shall be wronged..."

(Surah Āli-'Imrān, 3: 161)

The interpretation derivable from this verse is that it refers to the moral qualities of the Prophet (PBUH) and thereby emphasis the imperative of honesty and prohibition of any act that is tantamount to deceit and cheating in judicial proceedings. It reminds people, particularly those vested with the power, to settle disputes between contending parties and the need to be wary of the fact that they will be held accountable for their deeds and that everyone will be given their fair reward. ${ }^{80}$

\section{MAKING SHARIAH APPLICABLE IN NIGERIA}

In view of the Islamic position, this paper seeks to go beyond the constraints against Islamic principle resulting from the multi-religious nature of the country to propose an integration of Islamic cultural principles in fighting corruption, thus adopting a clear "second-order" preference for anti-corruption crusade. Consequently, a bold step to transform all the explained Islamic principles or measures as well as the Qur'ann and hadith referred in this paper to effective mechanism in the crusade against judicial corruptions, the following highlighted actions are suggested. In the first instance, it recommends incorporating the Shariah measures in the anti-corruption legislations that are relevant and applicable in fighting corruption in Nigeria. Incidentally, application of Islamic law is not new to at least the Northern part of the country even though its application is in a limited sense. Additionally, it proposes the establishment of monitoring body and its incorporation into the existing commissions. Investing organisation such as the Nigerian Supreme Council for Religious Affairs (NSCRA) with adequate powers to ensure compliance with anti-graft laws can go a long way in fighting corruption. It also suggests the strengthening of legal enforcements on the issues of corruption by extending the jurisdiction of Shariah Court to try anti-corruption cases, especially where the culprit is a Muslim.

80 Mohamed, A. A., 'Corruption and Bribery in Islam,' 177. 
Further understanding of how application of Shariah can work in the crusade against corruption in Nigeria can be shown from the Zamfara and Kano enactments of Shariah Penal Codes and provisions against anti-graft. For instance, Zamfara state has established Zamfara's Anti-Corruption Commission (Establishment) Law 2003 (ACC). ${ }^{81}$ Prosecutions under the law may be in either of two classes of courts created and managed by the State: Upper Shariah Courts (for Muslims) or District Courts (for non-Muslims); prosecutions under the ICPC Act are in the State High Courts, a step up the judicial ladder. In the same vein, Zamfara's Law specifies an interesting range of "punishments" for corruption, i.e. the ACC can recommend to the appropriate authority or office in case it concludes an official has erred, ranging from "admonishing ( $w a$ 'az)" through "transfer or suspension" to "prosecution and or dismissal from the service." 82

Like Zamfara State's first Anti-Corruption Commission, Kano's Directorate of Public Complaints and Anti-Corruption was created under the state Shariah Penal Code (Harmonized) Law 2003 which combine two functions of "corruption-fighter" and "ombudsman", (1) receiving, investigating, and if appropriate prosecuting allegations of corrupt practices against public servants, on the one hand, and (2) receiving, investigating and acting on complaints of administrative injustices and official ineptitude, including administrative decisions based on mistakes, bias, or abuse of powers. Accordingly, Kano Shariah Penal Code provides severe penalty for corruption and this was achieved by redefining crime of corruption and putting it under the heading of Theft, and treated it as such. The law provides:

"Whoever is a public servant or a staff of a private sector including bank or company connives with somebody or some other people or himself and stole public funds or property under his care or somebody under his jurisdiction he shall be punished with amputation of his right hand wrist and sentence of imprisonment of not less than five years and stolen wealth shall be confiscated." 83

81 Zamfara State Anti-Corruption Commission Law 2003 No. 12 of 2003; assented to 28 July 2003; published in Zamfara State of Nigeria Gazette No. 1 Vol. 2, 10 October 2003, A1-A27

82 M.A. Musa et al., eds., Development of Zamfara State and the Introduction of Shariah Legal System Under the Leadership of the Executive Governor Alhaji Ahmad Sani (Nigeria: M.A. Musa et al., 2002), 145., see also section 17(2) of Zamfara Penal Code (Establishment) Law 2003.

83 Section 134B(1) Kano State Harmonised Shariah Penal Code Law, 2003. 


\begin{abstract}
"If the money or properties stolen are mixed with another different wealth it will all be confiscated until all monies and other properties belonging to the public are recovered. If the confiscated amount and stolen properties are not up to the amount the whole wealth shall be confiscated and he will be left with some amount to sustain himself." 84
\end{abstract}

The efforts of Zamfara and Kano States evidenced the workability of Shariah measures against corruption. Finally, this paper proposes the introduction of continuous religious and legal educations for judges and legal practitioners on the devastating effects of corruption to society. These propositions are based on the fact that Nigerians is naturally a religious society and religion has continuously been a powerful tool for gaining massive support from the populace. It is the paper contention that the integration of Shariah measures will serve as an important tool in eliminating corruption and the followers of Islam and other religions can learn each other.

\title{
IMPLICATIONS OF JUDICIAL CORRUPTION
}

\section{Trivial or Unfairly Critical Corruption}

Systemic unfairly critical corruption or bribery in the judicial system is a problem in many developing countries as well as in more developed countries. This can be fathomed from the example given above. Bribes offered by users of the legal system especially as fondly manifested in election petition cases may take many forms, illegal 'fees', gift for judges ${ }^{85}$ and intimidation like the incidence that occurred at Ekiti where thug invaded the court and beat judges to prevent the hearing of Ayodele Fayose's case. Court users pay just to get their case through the system, to influence the outcome of a given case, or to delay it. Bribes may be paid to the judge, or to assistant staff or lawyers to remove files or get the case assigned to a particular judge. Instructively, corruption may appear trivial but it clearly challenges court's impartiality undermine fairness and justice. Thus, where petty corruption is prevalent, it creates an additional barrier for ordinary citizens to access the justice system.

\footnotetext{
84 Section 134B(2) Kano State Harmonised Shariah Penal Code Law, 2003.

85 Nyamu-Musembi, C., 'Gender and Corruption in the Administration of Justice in TI (Transparency International),' Global Corruption Report (2007): 121-128.
} 
Widespread bribery also erodes trust in the courts and distorts their ability to perform their functions as impartial arbiters of disputes. ${ }^{86}$

\section{Judicial Bias in the Dispensation of Justice}

Another implication of corruption to justice is found in a judge's bias in political matters. The citizens' perceptions of such attitudes, especially in election disputes, undermines the role of the judiciary as a protector of citizens' rights as well as the credibility of elections vis-à-vis the state in its various manifestations. It leaves ordinary people without an effective recourse to justice when the state is the offending party or the petitioner is in power along with scant protection. This political bias is not necessarily consistent across all types of cases; it tends to tick in when the stakes are high, such as when the executive or other political office holders feel threatened. This attitude runs contrary to the Constitution which provides that:

"In the determination of his civil rights and obligations, including any question or determination by or against any government or authority, a person shall be entitled to a fair hearing within a reasonable time by a court or other tribunal established by law and constituted in such manner as to secure its independence and impartiality..." 87

It is thus particularly damaging for the courts' political accountability and their ability to impartially enforce the rules of the political system - for example in relation to election fraud ${ }^{88}$ Illegitimate political influences on judges take different forms. Some are clearly illegal (bribes, blackmail, threats, violence/ murder), while others stem from undue influence from the ways in which relations between the judiciary and other arms of government are organized, or reflect a legal culture where judges are expected to defer to political authorities.

86 Molele, C. and A. Makinana (2012), ANC sets it Sights on the Judiciary. Mail and Guardian, February 17, 2012, available at http://mg.co.za/article/2012-02-17-ancsets-its-sights-on-the-judiciary, accessed on 14 October 2015.

87 S. 36 (1) Constitution (Nigeria) (1999).

88 Gloppen, S., 'Courts and Power in Latin America and Africa,' in Democratization and the Judiciary: The Accountability Function of Courts in New Democracies, ed. Gloppen, S., R. Gargarella and E. Skaar (London: Frank Cass; 2004), 112. 


\section{Judicial Appointments}

Where the government is perceived to appoint deferential judges or friends to the bench, it damages trust in the judiciary, regardless of whether said judges are in fact biased in their rulings. In many countries, the executive is widely perceived as decisively influencing those who are appointed as judges - even when there are rules and institutions in place to prevent this from happening. Judicial bodies like the NJC or other bodies designated with a role in nominations are often effectively circumvented and politically biased. Rules of ratification or confirmation by parliament have limited effect, particularly in dominant party contexts. ${ }^{89}$

\section{Regulation of Finances (Salaries and Benefits)}

Control over the treasury gives many governments a stronghold if not a stranglehold over the courts by enabling them to strategically regulate not only judges' salaries and benefits, but also the running costs of the judiciary. ${ }^{90}$ In Nigeria, the judiciary commonly depends on statutory allocations and parliament for their budget and for the regulation of salaries and benefits.

\section{Undue Influence via the Internal Judicial Hierarchy}

In many cases, undue influence on judicial rulings comes not from politicians directly, but via the judicial hierarchy. ${ }^{91}$ The controversy accompanying the unrest of the Sokoto State Election Petition Tribunal judgment led to the suspension of the former President of Court of Appeal Justice, Ayo Salami, is an evidence of this scenario. Such influence may be the result of direct pressure from superiors; subtler incentives based on judges' anticipation that a 'wrong' decision in an important case could have career consequences; or selective allocation or cases to judges who are likely to rule in a particular manner. Besides, internal procedures can be misused to limit individual judges' abilities to voice criticism, for example by refusing dissenting judgments.

89 Matei, A. \& Matei, L., 'Assessing the Anti-Corruption Strategies: Theoretical and Empirical Models,' 2/1, Journal of Management and Strategy, (2011): 23-40.

90 Ekwueme, E. G. \& Daminabo, A.F.D, 'Corruption in Education: The Nigerian Experience,' Journal of Vocational Science and Educational Development, 8/1 (2008): 109-11.

91 Gloppen, S. \& Kasimbazi, E., 'Elections in Court: the Judiciary and Uganda's 2006 Election Process,' in Electoral Democracy in Uganda, ed. Kampala, J. Kiiza, S. Mahara \& L. Rakner (2008), 53-89. 
This is another perspective to the manifestation of corruption in the judiciary, especially where the judicial leadership, and in particular the chief justice is seen close to the established regime.

Regardless of the NJC's efforts in purging the judiciary of corruption, it is argued that corruption in the institution is undoubtedly widespread. Given the apparent scale and detriment of corruption to the cause of justice it is essential to understand the mechanisms at play and examine efforts to address it.

\section{CONCLUSION}

Based on the preceding discussions, it is concluded that the country should attempt at a Shariah-based approach to positively contribute to the fight against corruption. Furthermore, it is concluded that although the NJC is seriously fighting corruption within the judiciary, the fight has not been successful due to several factors, which include lack of adequate supervision and the societal contextual factors that prevail in Nigeria. Finally, an Islamic model of fighting corruption cannot be absolutely achieved unless corruption is tackled through moral and ethical educational dimensions. This could be designed to inculcate in judicial officials a clear preference for judicial accountability, integrity, virtuous behavior - all reinforced by legal structures and administrative systems reflecting and supporting the pursuit for a corrupt free judicial institution.

Although this may appear worse to the Western world, there is probably less controversy in Islam as to the meanings of corruption and approaches to eradicate the phenomenon. Quite interestingly, Islam perceives a harmony among different conceptions of ethics. Thus all corrupt acts are considered susceptible to undermining societal harmony (in effect, the maximum good for the highest number) in one way or other.

\section{REFERENCES}

Abimbola, J. O. \&Adesote, S.A., 'Good Governance and National Development in Nigeria: A Critical Analysis,' in Nation Building and Sustainable Development in Nigeria, ed. Falade D.A and Gbade Ikuejube (Ibadan: Alafas Nigeria Company, 2012).

Bassiouni M. \& Gamal B., 'The Shariah: Sources: Interpretation and RuleMaking', UCLA Journal, 1 (2002).

Bello-Imam, I. B., The War Against Corruption in Nigeria: Problems and Prospects (Ibadan: Ibadan College Press \& Publishers, 2014).

Bryan A. G., Black's Law Dictionary, $8^{\text {th }}$ ed. (USA: Thomson West, 2007). 
Buscaglia, E., Judicial Corruption in Developing Countries: Its Causes and Economic Consequences (Palo Alto, Stanford, CA: Hoover Institution Press, Passim 1999).

Comparison of Conviction (2010-2014), 'EFCC Annual Report,' http://www. efccreport.org.ng, accessed on 18 May 2016.

Ekwueme, E. G. \& Daminabo, A.F.D, 'Corruption in Education: The Nigerian Experience,' Journal of Vocational Science and Educational Development, 8/1 (2008): 109-11.

Engy A., 'To Judge or not to Judge: A Comparative Analysis of Islamic Jurisprudential Approaches to Female Judges in the Muslim World, (Indonesia, Egypt and Iran),' Fordham International Law Journal, 37 (2014).

Falola, T. A., Mahadi, M U. \& Anyanwu, U., 'History of Nigeria: Nigeria in the Twentieth Century', (Ibadan: Longman Group Limited, 1991)

Gloppen, S. 'Courts and Power in LatinAmerica andAfrica,' in Democratization and the Judiciary: The Accountability Function of Courts in New Democracies, ed. Gloppen, S., R. Gargarella and E. Skaar (London: Frank Cass, 2004).

Gloppen, S. \& Kasimbazi, E., 'Elections in Court: the Judiciary and Uganda's 2006 Election Process,' in Electoral Democracy in Uganda, ed. Kampala, J. Kiiza, S. Mahara and L. Rakner (2008).

Gloppen, S., Gargarella, R. \& Skaar, E., eds., Democratization and the Judiciary: The Accountability Function of Courts in New Democracies (London: Frank Cass, 2004).

Hussein M., 'Bribery in Islamic Jurisprudence: A Comparative Analysis between Islamic Law and Positive Law,' Journal of Islamic Jurisprudence, 22 (1984).

Ibrahim Imam et al., 'Corruption in Nigeria: A Call for an Aggressive Legal Solution,' UNIZIK JIL, (2010): 134-145.

Imber, C., The Islamic Legal Principle (Stanford: Stanford University Press, 1994).

Iyoha, F.E \& Enabunene, S., 'Corruption and Crime in Nigeria: Impact on National Development,' Nigeria Journal of Contemporary Issues, ed. Arowolo, O., Fabarebo S. I. (2005).

Joseph Schacht, An Introduction to Islamic Law (London: Oxford Clarendon Press, 1973).

Kamal Mohammed Hashim, Principles of Islamic Jurisprudence (London: Cambridge Islamic Text Society, 1991). 
Khadduri, M., The Islamic Conception of Justice (Baltimore: Johns Hopkins University Press, 1984).

Lodge, R., 'Political Corruption in South Africa', Journal of African Affairs, 97 (1998).

Matei, A. \& Matei, L., 'Assessing the Anti-Corruption Strategies: Theoretical and Empirical Models,' 2/1, Journal of Management and Strategy, (2011): 23-40.

Mauro, P., 'Corruption and Growth,' Quarterly Journal of Economics (1995): 681-712.

Mohamed, A. A., 'Corruption and Bribery in Islam,' Annual Survey of International and Comparative Law, XVIII, ICL (2012).

Nyamu-Musembi, C., 'Gender and Corruption in the Administration of Justice in TI (Transparency International),' Global Corruption Report (2007).

Nye, J. S., 'Corruption and Political Development: A Cost Benefit Analysis,' in American Political Science Journal, ed. Arnold J. H., 51/2 (1967): 566-67.

Oko, O., 'Subverting the Scourge of Corruption in Nigeria: A Reform Prospectus', Journal of International Law and Politics, 34 (2015): 397473

Osoba, S. 'Corruption in Nigeria: Historical Perspectives', Review of African Political Economy, 23/69 (1996): 371-386.

Otite, O., Sociological Study of Corruption in Nigeria (Ibadan: Ibadan University Press, 1986).

Oyebode, A., 'The Judiciary, Corruption and Democratization,' Corruption and Democratisation in Nigeria, ed. Gboyega, A. (Ibadan: Ibadan University Press, 1996), 81-90.

Pogoson, A. I., 'Globalization and Anti-Corruption Reform in Nigeria: 2003-2007,' in Anti-Corruption Reform in Nigeria Since 1999: Issues, Challenges and the Way Forward, vol. 3, ed. Ekweremadu, D. U. and Okafor E. E. (Ibadan: IFRA Special Research Issue, 2009), 123.

Ribadu, N., 'Corruption: The Trouble with Nigeria', (A paper Presented at the 3rd Annual National Trust Dialogue, 2006)

Ribadu, N., 'Problems Associated with the Enforcement of Economic Crimes,' (Paper presented at the Nigeria Bar Association Conference Abuja, 2004).

Rose-Ackerman, Susan, 'Trust, Honesty and Corruption: Reflections on the State Building Process,' European Journal of Sociology, 1/2 (2001): 3841. 
Rosen, L., 'The Anthropology of Justice: Law as Culture in Islamic Society,' (1989).

Schleifer, A. \& Vishny, R., 'Corruption,' Quarterly Journal of Economics, 108/3 (1993): 599-617.

Shah, A., 'Tailoring the Fight against Corruption to Country Circumstances,' Performance, Accountability and Combating Corruption, ed. Shah A. (Washington, D. C.: The World Bank Report, 2007).

Stapenhurst, F. \& Langseth, P., 'The Role of Public Administration in Fighting Corruption', International Journal of Public Sector Management, 10/5 (1997): 311-330.

Szeftel, M., 'Misunderstanding African Politics: Corruption and the Governance Agenda', Review of African Political Economy, 76 (1998): 219-240.

Tignor, R., 'Political Corruption in Nigeria before Independence', Journal of Modern African Studies, 12/10 (1993): 175- 202.

Ubeku, A. K., 'The Social and Economic Foundations of Corruption and Other Economic Crimes in Nigeria', Perspectives on Corruption and Other Economic Crimes in Nigeria, ed. Ajibola Bala (Lagos: Federal Ministry of Justice, 1991), 41-43.

Ugochukwu, B., Democracy by Court Order: An Analytical Evaluation of the 2007 Election Petition Tribunals in Nigeria (Lagos: Legal Defence Centre, 2009).

Weimann, G., 'Judicial Practice in Islamic Criminal Law in Nigeria 2000 to 2004: A Tentative Overview,' Islamic Law \& Society Journal, 14/2 (2007): 240-286.

Weiss, B. G., The Spirit of Islamic Law (Athens: University of Georgia Press, 1998).

Yusuf Abdullah Al-Qardawi, The Lawful and the Prohibited in Islam (Shams Pirzada Trans., 1996).

Zafar Iqbal \& Mervyn K. L., 'Governance and Corruption: Can Islamic Societies and the West Learn from Each Other?', American Journal of Islamic Social Sciences, 19 (2002): 12-13.

Zubaida, S., Law and Power in the Islamic World (London: I.B. Tauris, 2003). 